\title{
Ulrich Beck ve Anthony Giddens'ın Risk Toplumu Kavramsallaştırması Işığında Sosyal Medya ve Bilginin Güvenliği ve Gizliliği İlkesi
}

Aykut SIĞIN*

\begin{abstract}
Öz
Modernite kavramı her zaman için sosyolojik tartışmaların merkezinde yer almıştır. Bunun başlıca sebebi, sosyoloji disiplininin modern çağ içerisinde ortaya çıkmış olması ve modern toplumu incelemesidir. En basit ifadesiyle geleneksel olandan bir kopuşa işaret eden modern sözcüguünden türetilen modernite, kimi düşünürlere göre son bulmuş ve yerini post-modern döneme bırakmıştır. Buna katılmayan geç modernite kuramcıları ise moderniteden bir kopuştan çok, bir değişim ve dönüşüm sürecine odaklanılması gerektiğini savunmuşlardır. Bir geç modernist olan Ulrich Beck, ikinci modernite kavramını ortaya atmış ve bu dönemin risk kavramıyla tanımlanması gerektiğini iddia etmiştir. Diğer bir geç modernist olan Anthony Giddens ise risk olgusunu modernitenin tek sonucu olarak değil, birden fazla sonuçtan bir tanesi olarak değerlendirmiş ve risk toplumu kavramı bu iki düşünürün argümanları doğrultusunda şekillenmiştir. Mevcut çalışmada, dijital çağın Beck ve Giddens'ın risk toplumuyla ilgili iddialarına uygun bir görünüm sergilediği düşüncesinden hareket edilmiştir. Bu doğrultuda, dijital çağın önemli dönüştürücülerinden biri olan sosyal medya platformları, bilginin güvenliği ve gizliliği ilkesi bağlamında bir risk olarak kuramsal bir tartışma ekseninde ele alınmıştır. Çalışmanın sonucunda, risk toplumu kavramsallaştırmasına uygun olarak teknolojik gelişmelerin risk olgusuyla bağlantısının artan bir şekilde devam ettiği ve bunlarla baş edebilmek adına bireysel önlemlerin alınması gerektiği anlaşılmıştır.
\end{abstract}

Anahtar Kelimeler: (Post-)modernite, Risk Toplumu, Dijital Çăg, Sosyal Medya, Bilginin Güvenliği Ve Gizliliği

\section{Social Media and Information Security and Privacy in Light of Ulrich Beck and Anthony Giddens' Conceptualization of Risk Society}

\begin{abstract}
Modernity has always been at the center of sociological debates. The main reason for this is that sociology emerged in the modern age, studying modern society. Modernity, which points to a break from the traditional, has come to an end according to some thinkers, giving way to post-modernity. However, late modernity theorists opposing this idea argued that the focus should be on a change and transformation process rather than a break from modernity. Ulrich Beck, a late modernist, introduced the concept of second modernity and claimed that this period should be defined with the concept of risk. Another late modernist, Anthony Giddens, evaluated risk as one of the multiple consequences of modernity and the concept of risk society was shaped with their arguments. This study maintains that the digital age presents an outlook suitable with Beck and Giddens' claims about risk society. Accordingly, social media platforms were taken as a risk within the context of the principle of information security and privacy in a theoretical discussion. At the end of the study, it was understood that, the connection of technological developments with the notion of risk continues increasingly and individual measures should be taken to cope with them.
\end{abstract}

Keywords: (Post-) Modernity, Risk Society, Digital Age, Social Media, Information Security and Privacy

Geliş/Received: 01.03.2021

Kabul/Accepted: 25.06 .2021

- Bu çalışma, insanlardan veri ve örnek toplamayı gerektiren, anket, inceleme, alan çalışması ve deney içeren araştırmalar kapsamına girmediğinden etik kurul onay belgesi gerektirmemektedir.

\footnotetext{
* Dr. Öğr. Üyesi, Aksaray Üniversitesi Fen Edebiyat Fakültesi Sosyoloji Bölümü, aykutsgn@gmail.com, ORCID ID: 00000002-1197-552X

(Makale Türü: Araştırma Makalesi)
} 


\section{Giriş}

Toplumsal yaşantıyı, ekonomiyi, zamanın ve mekânın kullanımını ve deneyimini daha önceki dönemlere kıyasla daha radikal bir biçimde etkileyen modern çağ üzerine hem dönemin düşünürleri hem de onları takip eden düşünürler tarafından birçok analiz yapılmıştır. Modern çağın veya modernitenin tam olarak ne zaman başladığını söylemek mümkün görünmese de sürecin Rönesans hareketini takiben 15. yüzyıl itibariyle Avrupa'daki toplumsal yaşantıyı şekillendirmeye başladığı söylenebilir (Linehan, 2009: 157) ${ }^{\dagger}$. Modern çağı bireycilik, kapitalizm, kentleşme, teknolojik ve yenilikçi siyasi gelişmelere olan inanç, ilerleme, rasyonalite, pozitivizm ve hümanizm gibi olguların karakterize ettiği öne sürülebilir. Hızlı ve kökten değiş̧imlerin yaşandığı ve dinin, geleneklerin, göreneklerin ve eski normların etkisini yitirmeye başladığı modern çağ, aslında bir "eski olandan kopuş", "geleneksel olanın yerine modern olanı tercih etme" süreci olmuştur.

Modernite üzerine yapılan tartışmaların sosyoloji disiplininde büyük bir yer edindiği bilinmektedir. Aslına bakılacak olursa, "modern" kategorisinin kendisi büyük ölçüde sosyolojinin bir ürünüdür ve bilim insanları 19. yüzyılda insan örgütlenmesinin yeni bir biçimi olan “toplum” u anlamaya çalışmak için bu disiplini yaratmışlardır. (Gelenekselden/eskiden) bir kopuş tezi olarak modernite, Fransız demokratik ve İngiliz sanayi devrimlerinin kutsal değerlerin itibarını düşürmek ve bunlarla bağlantılı sosyopolitik hiyerarşileri bozmak suretiyle daha önceden var olan yerel toplulukları ve bunların geleneklerini sarstığına vurgu yapmaktadır. Geleneksel/modern dikotomisinin modern tarafında bulunan sosyologlar, insan var oluşunun ölümsüz geleneklerin ve ruhsal inançların teselli edici kesinlikleri olmaksızın düşünülmesi gerektiğini ifade etmişlerdir. Bunun bir sonucu olarak modern öznenin gelişimi, kıyametbilimsel bir anlatının bir parçası olmaktan ziyade, açık uçlu ve sürekli olarak değişen bir süreç olarak ele alınmalıdır (Lash ve Friedman, 1992; Shilliam, 2017, 5216).

Klasik dönem sosyologlardan Durkheim için geleneksel toplumlar mekanik dayanışma sergilemektedir, çünkü birey kolektif bilince kurumsal yollar aracilığıyla değil, doğrudan bağlidır. Kendi eylemliliklerinin öznesi olamayan bireyler Durkheim'ın mekanik metaforunda görüldüğü gibi nihayetinde inorganik varlıklardır. Diğer yandan, sanayileşme daha karmaşık bir iş bölümünü doğurmuştur ve bunun sonucunda ortaya çıkan yeni dayanışma türü, gücünü bireyin kişilik gelişimini desteklemesinden almaktadır. Hem parça hem de bütün "canlı" olduğu için modern toplumun ortaya koyduğu dayanışma türü organiktir (Durkheim, 1964: 124, 131). Marx ise kapitalist moderniteyi kapitalizm öncesi üretim tarzları üzerinden ayırt etmiştir. Kapitalizm öncesi üretim tarzında iş bölümü, üreticinin umumi olarak düzenlenen toprağa doğrudan erişimi üzerinden tertip edilmekte ve sömürü, toprak ağası ile serf arasındaki hiyerarşik ilişkilerde gözlemlenen bireysel bağımlılık üzerinden

\footnotetext{
+ Sosyoloji disiplininden gelenler ise genel olarak modernitenin başlangıcı olarak 18. yüzyılın sonlarına işaret etmektedir (Shilliam, 2017, 5215), çünkü o dönemde yaşanan sanayi devrimi, insanlığın moderniteye doğru attığı en somut adım olarak kabul edilmektedir.
} 
ilerlemektedir. Kapitalist üretim tarzında ise toprak ve emek meta hâline gelmiş, bireysel ve umumi bağlılıklarını yitirmiştir (Marx, 1973: 156-166). Klasik dönem sosyologlardan bir diğeri olan Weber ise modern toplumsal eylem biçimlerinin neden ve nasıl araçsal rasyonalite içerdiğini anlamak üzere din kurumuna bakmıştır. Weber için Protestan ahlâkı dünyevi zevklere kendini kaptırmamayı ancak bunun yanında da dünyadan uzaklaşmayı değil de çileci emeği buyurduğu için tarihsel açıdan önemli bir yerde durmaktadır. Kapitalizmin doğuş felsefesi ve Protestanlık arasında bağlantı kuran Weber, moderniteyi dünyanın büyüsünün bozulmasında, rasyonalitenin ve buna bağlı olarak da kural yönelimli bürokrasinin ön plana çıkmasında temellendirmiştir.

Sosyoloji, modern toplumun bilimi olduğu için hem modernitenin nesnesi hem de ona dair tartışmaları ürettiği için öznesidir. Herhangi bir dönemin düşünürlerinin o dönemin koşullarından bağımsız fikirler ortaya koymasının ne kadar zor olduğu düşünüldüğünde klasik dönem sosyologların modern topluma ilişkin kuramlar geliştirmiş olmaları anlaşılır bir hâl almaktadır. Durum, modernitenin miadını doldurduğunu düşünen ve "moderniteden sonrasını" inceleyen post-modernistler söz konusu olduğunda biraz daha düşündürücü olmaktadır, çünkü post-modernistler yeni bir dönemin anlatısını yaparken bu yeni dönemin nasıl olduğundan çok, nasıl olmadığından bahsetmektedirler. Bu bağlamda, post-modern felsefe en temelde, moderniteyle ilişkilendirilen meta anlatılara ve ideolojilere şüpheyle yaklaşan veya bunları doğrudan reddeden bir anlayış olarak okunabilir (Lyotard, 1984). Aydınlanma rasyonalitesi post-modernistler tarafından eleştirilmiş, bunun bir uzantısı olarak da modernitenin "nasıl bilebiliriz?" temelli epistemolojik sorularından uzaklaşılıp kimliği neyin inşa ettiğine yönelik ontolojik sorulara odaklanılmıştır.

Ancak nasıl ki modernite kavramsallaştırması içerisinde (gelenekselden/eskiden) bir kopuş anlatısı taşıyorsa, post-modernite kavramı da aynı şekilde bir kopuşa işaret etmektedir. "Post-modern" ifadesini, 1979 yılında yayımlanan "La Condition Postmoderne: Rapport Sur Le Savoir"” başlıklı eserinde ilk kez felsefi bir bağlamda kullanan Lyotard (1984: xxiii), kavramı 19. yüzyılın sonlarından itibaren gözlemlenen kültürel dönüşümleri ve bunlara bağlı olarak bilimde, edebiyatta ve sanatta değişen “oyunun kuralları”ndan bahsetmek üzere ele almaktadır. İnsanlık tarihine periyodik olarak yaklaşmak bir dönemin ne zaman bitip bir diğerinin ne zaman başladığını saptamak zor olduğu için sorunludur. Kimi düşünürlere göre, insanlık post-modern çağ 1 yaşamaktayken kimilerine göre modern çağ hâlâ devam etmektedir. Öte yandan, post-modernizmin İkinci Dünya Savaşı'nın modernizmin algılanan başarısızlıklarını ortaya koyması sonucunda ana akım kültürü açıklamak üzere kullanılan bir kavram olduğu genel olarak kabul görmektedir.

Bir tarihsel dönemin başlangıcını ve bitişini belirleyen faktörlerin belirlenmesindeki sorunların yanı sıra, o döneme verilen ad(lar) da tartışmaları beraberinde getirebilmektedir. Öte yandan, içinde

\footnotetext{
‡ Türkçeye "Postmodern Durum” başlı̆̆ıyla çevrilmiştir.
} 
Ulrich Beck ve Anthony Giddens'ın Risk Toplumu Kavramsallaştırması Işığında Sosyal Medya ve Bilginin Güvenliği ve Gizliliği İlkesi

bulunduğumuz dönemi karakterize eden faktörlerin belirginliğinden ötürü söz konusu sorun, kendisini geçmiş dönemlere kıyasla daha az göstermiştir. Bu doğrultuda bilgi ve verinin öneminin sınai üretimin önüne geçmesiyle birlikte içinde bulunduğumuz dönem bilgi çağı, elektronik çağ, bilgisayar çağ1, internet çağı, siber çağ ve dijital çağ gibi adlarla anılır olmuştur ${ }^{\S}$. Özellikle internet altyapısını kullanarak (kurum ve kuruluşların aksine) bireylerin kendi içeriklerini üretmelerini ve anlık olarak dünyayla paylaşmalarını sağlayan yeni medya, geleneksel medyanın çoğu zaman tek yönlü iletişim modeline bir alternatif sunmuş, önayak olduğu iletişim devrimiyle mevcut dönemin en önemli sembollerinden birisi hâline gelmiştir.

Daha önce de değinildiği gibi, modernite ile ilgili tartışmalara sosyologlar tarafından sıklıkla yer verilmiştir. Modernitenin sosyolojisinin temellerini atan Durkheim, Marx, Weber, Tönnies, Simmel, Mead gibi sosyologların dışında; Giddens, Bauman, Beck, Ritzer, Habermas gibi sosyologlar da modern toplumun analizine önemli katkılar sunmuşlardır. Bu çalışmada modernitenin çağdaş kuramcılarından Ulrich Beck ve Anthony Giddens'ın risk ve risk toplumu kavramları ele alınıp günümüz toplumsal yaşantısını değerlendirmek üzere kullanılacaktır. Bu doğrultuda, yeni medya başlığı altında ele alınan sosyal medyanın yarattığı riskler, özel hayatın gizliliği ve kişisel verilerin korunması özelinde tartışılacaktır.

\section{Ulrich Beck ve Anthony Giddens'ta Risk ve Risk Toplumu}

Risk, modern toplumdan, dolayısıyla da Beck ve Giddens'tan çok daha önce var olmuş bir kavramdır. Bundan dolayı etimolojik bir araştırma yapmanın yerinde olacağı düşünülmektedir. Uludağ (2020: 5), risk kavramının kökeni olarak Antik Çağ'a işaret etmektedir. Antik Yunanlılar "rhizikon" sözcügünü "sakınılması gereken bir kaya veya başka bir tehlike" anlamına gelen bir gemicilik terimi olarak kullanmışlardır. Latince'de de aynı anlamı taşıyan "riscus” sözcüğü bulunmaktadır. Arapça'ya "yaratıcı tarafından geçim için verilen her şey" veya "işin veya zahmetin kesin olmayan sonucu" anlamına gelen "rizq” şeklinde geçen bu sözcük, 1500'lü yıllarda Avrupa'da yeniden tehlikeyi çağrıştıracak şekilde "rysigo" (Almanca), "risco" (İtalyanca) ve "risquer" (Fransızca) biçimlerine bürünmüştür (Brown, 2015). Bu bağlamda bir risk tanımlaması yapılırken istenmeyen bir durum, aksilik veya tehlikenin gerçekleşme ihtimalinden bahsedilebilir. Aslına bakılacak olursa, Arapça'dan Türkçe'ye geçen rızık (rizq) kavramı da bir bilinmeyene işaret etmektedir. Tüm bu bilgiler ışığında risk söz konusu olduğunda akla gelmesi muhtemel kavramların ihtimal, bilinmezlik ve tehlike olduğu söylenebilir.

Modern öncesi dönemde ve günümüzde tehlikeden bahsedildiğinde akla gelen şey aynı değildir. Öyle ki, modern öncesi dönemde tehlikelerin kendiliğindenliği ve rastlantısallığı daha ön plandayken günümüz söz konusu olduğunda bireyin kendi oluşturduğu ve bütün canlıları tehdit ettiği boyutu önem

\footnotetext{
$\S$ Mevcut araştırmacı bu çalışmanın içeriğine en çok dijital çağ kavramının uygun olduğunu düşünmekte, bu yüzden de içinde bulunulan döneme atıfta bulunmak için bu kavramı kullanmayı tercih etmektedir.
} 
kazanmaktadır (Uludağ, 2020: 6). Bu durum, aydınlanma hareketiyle birlikte görülmeye başlanan pozitivist, antroposantrik ve rasyonel sosyo-kültürel ortamın doğal bir sonucudur: Aklı dolayısıyla kendisinin diğer canlılardan üstün olduğunu düşünmeye başlayan aydınlanma insanı, bu retorikten hareketle, daha önce doğanın sunduğu tehlikeler karşısında edilgen durumda olma ve onlardan korkma hâlini bir kenara bırakmıştır. Aydınlanma insanı, doğaya hükmetmeye başlamış ve kendisini büyük ölçüde doğanın üstünde konumlandırmıştır. Daha önce doğanın yönlendirmelerine bağlı bir şekilde ve onun içerisinde hareket eden insan, artık onu incelenmesi gereken bir olgu olarak görmeye başlamıştır. Örneğin, daha önceleri bir doğa olayı sonucunda bulunduğu yeri değiştirmek zorunda hisseden insan, artık söz konusu doğa olayına karşı önlemler alabilmeyi öğrenmiştir. Daha sağlam yapılar inşa etmeyi öğrenen insan, bir deprem veya yangın durumunda doğanın kanunlarını olduğu gibi kabul etmek yerine onlarla savaşma yolunu seçmiştir. Ancak doğa üzerine kurulan bu hakimiyet modern insanın hayatından tehlike ve risk kavramlarını çıkarmamış, bunları dönüştürmüştür.

Modern dönemin farklılık arz eden risk anlayışı, bu kavramın sosyal bilimlerde detaylı olarak incelenmesi gerekliliğini ortaya çıkarmıştır. Risk üzerine yapılan sosyolojik analizlerden en kapsamlısının Beck'in "risk toplumu" kavramsallaştırması olduğunu söylemek mümkündür. Öte yandan, Beck'in risk tezine değinmeden önce "modernden bir kopuş olarak post-modern" tartışmalarında nerede durduğunu bilmenin onun risk yaklaşımının daha iyi anlaşılmasına katkı sağlayacağı ileri sürülebilir. Alman sosyolog, post-modernizmi reddetmektedir. Ona göre, "modernin ötesinde" bir dünyada yaşamaktan ziyade, "ikinci modernite”ye doğru yol alan bir aşamada yer almaktayız. İkinci modernite ise modern kurumların küresel bir hâl alırken günlük yaşamın gelenek ve göreneklerin etkisinden koptuğu iddiasına dayanmaktadır. Eski sanayi toplumu yok olmakta ve yerini risk toplumuna bırakmaktadır. Beck, post-modernistlerin kaos veya bir örüntü yokluğu olarak gördüğü şeyi, risk veya belirsizlik olarak görmüştür. Risk yönetimi, küresel düzenin birincil özelliğidir. Bilimin ve teknolojinin gelişmesi, daha önceki çağlarda görülmemiş risk durumlarının ortaya çıkmasına zemin oluşturmuştur. Beck, kavramsallaştırmasını ortaya koyarken sürece bütünüyle kötümser bir pencereden bakmaz; bilimin ve teknolojinin insanlara birçok fayda sağladığını kabul eder ancak ölçülmesi güç riskler de yine bilim ve teknoloji tarafindan yaratılmaktadır ("Sociology Guide", 2021).

Beck'in "Risikogesellschaft" başlıklı çalışması Sovyetler Birliği’nde yaşanan Çernobil faciasının hemen ardından yayımlanmıştır ve ekolojik kriz, bu sosyal analizin temelini oluşturmuştur. Ekolojik riskler Beck için sanayi toplumlarının baş edilebilir bir yan etkisi olmaktan öte, başlıca ürünü olmuştur. Doğaya hükmetmeye başlayan sanayi toplumu insanı, daha önce maruz kaldığı doğal afetler gibi risklere karşı önlem alabilmenin yolunu öğrenmiştir. Bu dönem insanı, kurduğu fabrikalar sayesinde sanayi öncesi dönem insanını öldüren ölümcül hastalıklara karşı ilaçlar geliştirmiş ve kendisini bu hastalıklardan korumayı başarmıştır. Ancak bu fabrikalar çevre kirliliğine yol açmış, daha farklı hastalıkların boy göstermesine sebebiyet vermiştir. Bu bağlamda, sanayi toplumlarında 
Ulrich Beck ve Anthony Giddens'ın Risk Toplumu Kavramsallaştırması Işığında Sosyal Medya ve Bilginin Güvenliği ve Gizliliği İlkesi

karşılaşılan riskler çoğunlukla insan ürünüdür. Sanayi öncesi toplumun doğal riskleri yerini üretilmiş risklere bırakmıştır. Günümüz toplumlarında ise risk, küresel bir boyut kazanarak yalnızca bulunulan bölgeyi etkisi altına almanın ötesine geçmiştir. Dolayısıyla da bir fabrikanın, bir tek bulunduğu çevrenin havasını kirletmesinde görülen yerellik durumu artık dönüşmüştür. Slattery’e (2010: 455) göre,

Atomun parçalanması insana nükleer enerji yaratma gücü verdi. O insanoğluna ayrıca kitlesel imha silâhları yaratma araçları sağladı; DNA'nın şifresinin çözülmesi ona sadece genetik hayatın sırrını değil Tanrı’yı oynama ve klonlanmış insan yaratma gücünü de kazandırdı; fosil yakıtlar insanoğluna 200 yıllık küresel enerji sağlamıştır, ancak insanın bu tür yakıtları kendi çıkarı için ve tutumsuzca kullanması küresel ısınmaya yol açarak günümüzde gezegeni yok etme tehdidi yaratmaktadır. İnsan kendi evreninin kontrolünü daha fazla ele geçirdikçe, paradoksal olarak, hayata ve dünyaya yönelik risklerin, Doğu veya Batı, Kuzey veya Güneydeki tek tek ulusları ve toplulukları değil, aynı zamanda bütün insanlığı etkilediği ve çok daha büyük olduğu görülmektedir.

Beck'in daha çok makro bir çerçeveye sahip olan risk toplumu kavramsallaştırmasının mikro bir yanı da bulunmaktadır. Bir yanıyla neo-Marksizm'i aşmaya çalışan bir model sunan (Slattery, 2010: 454) eserinde Beck (1992: 91-92), sanayi toplumunun toplumsal sinıflara vurgu yaparken risk toplumunun bireyselliği ön plana çıkardığından söz etmektedir. Bu bağlamda, sanayi toplumunda ulaşı1mak istenen nihai hedef, refahtır. Öte yandan, risk toplumunda ise belirsiz bir geleceğe karşı bireyin kendisini güven altına alması başlıca amaçtır. Diğer bir ifadeyle, sanayi toplumundaki kâr edebilme güdüsü yerini basitçe hayatta kalabilme güdüsüne bırakmıştır. Esgin'in (2013: 688) ifadesiyle, "sınıflı toplumun ihtiyaç hâlindeki vatandaşlarının yerini, risk toplumunda kaygı hâlindeki vatandaşlar almıştır". Buradan hareketle, "günü kurtarmak" söyleminin bu çerçevede geliştiğini söylemek mümkündür. Özellikle kaderci toplumlarda sık sık işitilen "Bugün de sağ salim evimize girebildik.", "Bugünü de kazasız, belasız atlattık." tarzındaki ifadeler ("rızık” kavramıyla birlikte düşünüldüğünde) risk toplumunu karakterize etmektedir. Bunun da ötesinde; iş sözleşmeleri, emeklilik maaşları, sağlık sigortaları, senetler, taahhütnameler gibi yasal dayanağı olan uygulamalar öngörülemeyen geleceğe, risk dolu yarınlara karşı bir güvence oluşturmak adına ortaya çıkmıştır.

Risk toplumundaki üretilmiş riskler toplulukları, toplumsal sınıfları ve toplumları aşmaktadır. Aslında bu durumdan kaynaklı olarak risk büyümüş ama riskin deneyimlenişi "küçülmüş", bireyselleşmiştir. Sözgelimi, alt sınıfa mensup birisi ne kadar biyolojik bir savaşın getireceği riskleri taşıyorsa, üst sınıftan birisi de bu risklere aynı şekilde maruz kalabilmektedir. Diğer bir ifadeyle, risk toplumunun risklerinden tam anlamıyla kaçmak imkânsızdır ve toplumsal cinsiyet ve sınıf gibi değişkenler bu risklere karşı bir kalkan görevi görememektedir. Küreselleşen dünyada risk, hem tüm dünyayı kapsayacak bir noktaya erişmiş hem de bireyin iç dünyasına nüfuz eder hâle gelmiştir. İnsanlar risklere karşı bireysel sorumluluklar almayı öğrenmek zorunda kalmışlardır. Liberal bir atmosfer içerisinde her türlü özgürlüğe sahipmiş gibi görünen risk toplumu insanı, aslında dört bir yandan 
tehlikelerle kuşatılmış, bu anlamda karşılaşabileceği riskler karşısında çaresiz, donanımsızdır. Risklere karşı donanımsız olma durumu, sanayi devrimiyle birlikte doğaya hükmetmeye başlayan insanlar için tezat oluşturmaktadır. Doğayla kurulan tahakküm ilişkisi ruhsal ve psikolojik sorunları da beraberinde getirmiştir.

Risk toplumunda kolektivizmin yerini bireyselleşmeye bırakması durumunu Üvez (2014: 14) şu şekilde açıklamaktadır:

Toplumsal cinsiyet ve aile rolleri değişmektedir. Bu değişim düşünümsellik anlayışının ortaya çıkardığı bir sorundur. Düşünümsellik, bu sorunu sanayi toplumundaki toplumsal ve siyasal kurumlara ve örgütlere dayanan sınıf kültürü ve aile gibi "kolektif vicdan biçimlerine" son vererek gerçekleştirmektedir. Bununla birlikte, toplumsal sınıflara bağlılık gün geçtikçe zayıflamakta, insanlar aile ya da komşuluğun sağladığı geleneksel destek ağlarından kopmaktadır. Bu geleneksizleşme hali bireyselleşme halini daha da artırmaktadır. Bireyselleşmiş bir toplumda da yeni bir eşitsizlik ve bu eşitsizliğin getirdiği sosyal ve siyasi sorunlar ortaya çıkmıştır.

Söz konusu bireyselleşme, bireyin aldığ 1 şahsi kararlarla yaşam tarzını ve alışkanlıklarını değiştirmesini zorunlu kılmaktadır. Sigara içen bir kimse bunun sağlığ üzerinde oluşturacağ olumsuz etkileri bilir ve dolayısıyla sigarayı bırakma kararını verecek olan yine kendisidir. Beck'in kavramsallaştırmasındaki gibi kaotik bir toplumda hayatta kalmak isteyen birey, bilinç seviyesini yükseltmelidir. Risk, her an her yerdedir ve bu da bireyin yaşadığı her anı daha farkındalık sahibi olarak sürdürmesini gerektirmektedir. Aksi takdirde, risk toplumunun tehlikelerine karşı koyabilmek mümkün görünmemektedir. Burada dikkat çeken bir nokta Beck'in refleksif/düşünümsel modernite kavramsallaştırmasıdır. Slattery’e (2010: 456-457) göre, küresel iletişim araçları ve internet aracılığıyla daha çok iletişim kurup daha çok bilgi edinebilmekteyiz. Ancak Beck'in kavramsallaştırmasında bu durum mutlak iyi sonuçlar doğurmak durumunda değildir. Aksine, daha fazla iletişim ve bilgi, daha az kontrolü doğurmaktadır. Bir gıdanın besin değerliyle veya bir ilacın yan etkileriyle ilgili daha fazla bilgiye sahip olmak, beraberinde daha fazla korkuyu da getirmektedir. Öte yandan, bu kontrolsüzlük daha kaderci, daha vurdumduymaz bireyler hâline gelmemizi de sağlayabilir.

Refleksif modernite olgusu çerçevesinde değerlendirildiğinde, yaşanılan bireyselleşme aile ve din gibi toplumsal kurumlarda rahatlıkla gözlemlenebilmektedir. Refleksif modernite kavramı, moderniteyi onun bir önceki hâline karşı çıkması bağlamında düşündürmektedir. Birinci modernite nasıl feodal gelenekselliğe karşı çıkmışsa, ikinci modernite de birinci modernitenin kurumlarını ekonomik ve kültürel küreselleşme aracılığıyla çökertmiştir. Esnek çalışma şartları ve kadın özgürlüğünü takiben artan boşanma oranları sonucunda aile artık dağılmakta ve bu süreçte aile üyelerine destek sağlama işlevini yitirmektedir. Din kültürel bir ürün hâline gelmiş, şirketlerin ve sivil toplum kuruluşlarının yükselişiyle birlikte, ulus devlet eski önemini yitirmeye başlamıştır (Ray, 2007: 57). Buradan çıkarılacak sonuç, dayanışma ve otorite kaynağı olarak işlev gösteren eski kurumların bireyselleşmeyle olan 
Ulrich Beck ve Anthony Giddens'ın Risk Toplumu Kavramsallaştırması Işığında Sosyal Medya ve Bilginin Güvenliği ve Gizliliği İlkesi

refleksif ilişkilerinin sonucunda bu işlevlerini giderek yitirdiğidir. Bu kurumsal otorite yoksunluğunda birey kendi başının çaresine bakmayı öğrenmelidir.

Ulusal sınırların daha geçirgen bir hâl alıp ulus devletin eski gücünü muhafaza edemediği küreselleşme çağında toplumsal gerçeklik tamamıyla kozmopolit bir yöne doğru evrilmektedir. Kozmopolitliğin, idareli bir şekilde gelişmesine izin verilmediği takdirde, firsat görünümünde birçok tehdit barındırdığı söylenebilir (“Sociology Guide”, 2021). Sonuç olarak, Beck’in "küreselleşirken bireyselleşen" bu dünya tasviri risk üzerine inşa edilmiştir ve söz konusu risk olgusu bireysel anlamda toplumun üyelerini risk bilincine sahip olacak şekilde değiştirip dönüştürürken toplumsal kurumların mutlak otoritelerini yitirmelerine yol açmıştır.

Risk toplumu kavramını ortaya atan kuramcı Beck'tir ancak onu daha yaygın hâle getiren ismin Giddens olduğunu söylemek mümkündür. Giddens (1996: 7) moderniteyi karakterize ederken tartışmasını güvenliğe karşı tehlike ve güvene karşı risk etrafinda şekillendirir. Ona göre, toplumsal kurumların gelişip dünya geneline yayılmasıyla beraber insanlar için modern öncesi sistemlere kıyasla daha güvenli ve ödüllendirici fırsatlar ortaya çıkmıştır ancak buna karşılık daha tehlikeli ve risk dolu bir toplumda yaşadığımız da bir gerçektir. Risk ve risk toplumu olguları Giddens için modernitenin başlıca sonuçlarından bir tanesi olmakla birlikte, tek sonucu değildir. Dolayısıyla, Giddens bu noktada Beck'ten ayrılmaktadır.

Giddens'ın risk kavramsallaştırması bir kopuş anlatısına dayanmaktadır ancak söz konusu kopuş, modernle post-modern arasına çekilen bir çizgi değildir. Ona göre, geleneksel toplumların bir risk nosyonu bulunmamaktaydı. Bunun nedeni ise, riskin gelecekteki ihtimaller ekseninde aktif olarak değerlendirilen tehlikelere işaret etmesidir. Dolayısıyla da risk olgusu geleceğe odaklanmış ve geleceği fethedilecek veya kolonileştirilecek bir bölge olarak gören toplumlarda yaygın olarak kullanılmaktadır. Risk, geçmişten aktif bir şekilde kopmaya çalışan toplumları akla getirir ve bu da modern sanayi toplumunun temel özelliğidir (Giddens, 2000: 40).

Giddens riski tanımlarken “aktif” sözcüğünü ısrarla kullanmasına karşın, eylemsizliğin veya aktif olmamanın da riski uzaklaştırmadığına değinir ve Luhmann'ın risk kavramsallaştırmasına karşı bir duruş sergiler. Giddens (1996: 32), Luhmann'ın (2000: 97) “Bir eylemde bulunmazsanız, herhangi bir şeyi riske atmıyorsunuz demektir.” önermesine katılmadığını açıkça belirtir ve eylemsizliğin genellikle riskli olduğunu dile getirir. Ekolojik facialar veya nükleer savaşlar bizler istesek de, istemesek de birer risk olarak günümüz dünyasında karşımızda durmaktadır.

Yukarıda değinildiği üzere, Giddens moderniteyi bitmiş bir proje olarak gösteren ve onun arkasından post-modernitenin geldiğini öne süren iddiaları kabul etmemektedir. Giddens bir postmodernist değil, bir geç modernisttir. Geç modern kavramı kapsamında içinde bulunduğumuz dönem, modernitenin radikalleşmesi bağlamında ele alınmaktadır ve aslında risk toplumu, ikinci modernite, 
refleksif modernite, akışkan modernite ve üst modernite gibi kavramlar bu şemsiye kavram altında değerlendirilmektedir (Evre, 2011: 66). Geç modernistlere göre, modernliğin ötesindeki bir evreye geçilmesi söz konusu değildir; modernleşme günümüzde de devam etmektedir. Artık modernite, klasik tanımlamada olduğu gibi gelenekselliğe karşı bir süreç olarak değil, kendine içkin dinamiklere atıfta bulunarak açıklanmaktadır**.

Küreselleşme ve radikalleşmenin önemli yer edindiği modernite tanımlamasında Giddens, aydınlanma hareketinin temel niteliklerinden olan aklın, bilginin ve düşünmenin önemini koruduğuna vurgu yapmaktadır. Refleksif/düşünümsel modernite bireylerin toplumsal yaşantılarını nasıl sürdürecekleri bilgisini verir. Böylece, toplumsal pratikleri (yeniden) üreten birey, bir aktör olarak düşünümsel bir şekilde toplumsal yaşantıyı da var etmektedir. Modernite denilen şey, bizzat aktörlerin aktlarının (eylemlerinin) sonucudur. Bu anlamda, günümüzde karşılaşılan risklerle başa çıkabilmek için yine bireysel eylemlere gerek duyulmaktadır. Fail veya ne yaptığını bilen birey, Giddens'ın risk toplumunda başat aktördür (Esgin, 2013: 690). Modernite tarafından üretilmiş riskler, sonuçları ve getirdikleri belirsizlikler bağlamında bireyleri dönüştürmektedir. İçinde yaşadığımız çağ, öncekilerden daha tehlikeli veya riskli değildir ancak tehlike ve risk dengesi değişmiştir. Kendi yarattığımız tehlikeler dışarıdan gelen tehlikeler kadar, hatta onlardan daha korkutucudur. Gıda, ilaçlar, evlilik gibi konularda görüldüğü gibi, yaratılan bu tehlikeler insanları bireysel olarak doğrudan etkilemekte ve ilgilendirmektedir (Giddens, 2000: 52). Giddens'ın yapı ve fail arasındaki etkileşimi dinamik ve refleksif bir açıdan ele alan yapılaşma teorisi, modernite ve birey olarak da okunabilir.

Giddens'ın risk toplumunda da Beck'inkinde olduğu gibi insanın doğayla etkileşimi önemli bir referans noktasıdır. Giddens'a (2000: 44, 46, 48) göre, bütün geleneksel toplumlarda ve sanayi toplumunda insanlar doğadan gelecek sel, salgın, kıtlık gibi dış risklerden endişe duymaktayken günümüzde, doğanın insanlara ne yapabileceğinden ziyade, insanların doğaya ne yapmış olduğundan endişe duymaktadırlar. $\mathrm{Bu}$ durum, doğadan gelen dış risklerden insanların kendilerinin meydana getirdiği üretilmiş risklere geçişi gözler önüne sermektedir. Üretilmiş risk söz konusu olduğunda risk seviyesinin ne noktada olduğunu bilemeyiz ve çoğunlukla da çok geç oluncaya kadar bu bilgiye sahip olmamız mümkün değildir. Gelecekte olabileceklere yönelik birtakım kestirimlerde bulunabiliriz ancak risk kavramının yanıltmacı da burada kendisini göstermektedir: Sonuç, beklenildiği gibi olabileceği gibi, olmayabilir de.

Risk toplumunun kavramsal temellerini atan Beck ve Giddens, klasik modernitenin sosyolojik kavram ve teorik araçlarının bilimsel riskler ve teknolojik tehlikelerle dolu bir toplumsal görünümü açıklamak için yeterli olmadığını düşünerek çağdaş toplumun dinamiklerini incelemek üzere alternatif

\footnotetext{
${ }^{* *}$ Refleksif veya düşünümsel ifadesi bu noktada anlam kazanmaktadır. Giddens gibi geç modernistler post-modernistlerin yaptığı gibi bir kopuş tezi üretmek yerine, içinde bulunduğumuz dönemi kendi şartları içinde değerlendirmemiz gerektiğini ifade etmektedirler.
} 
Ulrich Beck ve Anthony Giddens'ın Risk Toplumu Kavramsallaştırması Işığında Sosyal Medya ve Bilginin Güvenliği ve Gizliliği İlkesi

bir sosyolojik imgelem sunmuşlardır. Sanayi çerçevesinde şekillenen birinci modernitenin kavramlarını ikinci, bilimsel modernitenin temelden farklı sorunlarına uygulamanın verimsiz olması tek mesele değildir. Mesele, aynı zamanda yeni sorunlara yeni çözümler üretmek, yeni gelişen teknolojilerin toplumsal etkilerini incelemek için yeni toplumsal kurum tasarıları yapmak ve yeni teknolojilerle bağlantılı olarak ortaya çıkan riskleri idare etmek için yeni düzenleyici sistemler ortaya koymaktır. Modernitenin ikinci, refleksif çağında ortaya çıkan teknolojik riskleri uygun bir şekilde idare edebilmek için "modernitenin senaryosunun yeniden yazılmaya, tanımlanmaya ve icat edilmeye ihtiyacı vardır" (Beck, 1998b: 9; Ekberg, 2007: 343-344). Bu bağlamda, (yeni gelişen) teknoloji(ler) risk toplumunda risk üretimi anlamında temel etkenlerden birisidir.

\section{Bir Risk Olarak Sosyal Medya ve Bilginin Güvenliği ve Gizliliği İlkesi}

Beck'in risk toplumu tezini ortaya attığ 1986 yılında dijital devrim olarak da bilinen üçüncü sanayi devrimi yaşanıyordu. İki dünya savaşının ardından sanayileşme ve teknolojik gelişme öncesine kıyasla yavaşlama göstermiştir ancak iletişim teknolojilerinin gelişmesi dijitalleşmenin etkisiyle hız kazanmıştır. Hem Beck hem de Giddens tezlerini teknolojiyle bağlantılandırmışlardır ancak doğrudan dijitalleşmeye odaklanmamışlardır. Bunun sebebi olarak 20. yüzyılın sonlarında dijitalleşmenin toplumsal etkilerine henüz gözle görülür bir şekilde rastlanmıyor oluşu gösterilebilir. 21. yüzyıl veya dijital çağ, dijitalleşmenin toplumsal etkilerinin daha görünür kılındığı ve tecrübe edildiği tarihsel dönem olmuştur. Bu anlamda, dijital çağı risk toplumu tezi üzerinden okumak sosyolojik açıdan önemli bir konudur.

Dijital çağın toplumsal ve bireysel yaşantıya etkisi en belirgin hâliyle sosyal medya üzerinden değerlendirilebilir. Öyle ki, işlerlik gösterebilmek için bilgisayar teknolojisine ihtiyaç duyan yeni medyanın bir parçası olarak düşünülen sosyal medya, dijital çağı hem makro hem de mikro boyutlarda şekillendirmeye devam etmektedir. Van Dijk’a (2006: 2) göre, günümüzde medya ağları, sosyal ağlar ve ekonomik ağlar dünyanın bir ucundan diğer ucuna kadar yayılmaktadır ve dünya tam anlamıyla küresel bir bağlantıya kavuşmuştur. Uydu teknolojisinin, cep telefonlarının ve internetin hızla yaygınlaşmasıyla, gelişmekte olan ülkeler sanayi öncesi toplum görünümünden çıkarak sanayi toplumlarına ve hatta sanayi sonrası ağ toplumlarına dönüşmüştür. 21. yüzyıl ağlar çağı olarak da anılabilir. Ağlar, toplumun sinir sistemi hâline gelmektedir ve insan bedeninde hücreler arasında iletimi sağlayan bu sistem, toplumsal hayatta da yapılar ve aktörler arasında aynı işlevi göstermektedir. İspanyol sosyolog Manuel Castells, ağ tabanlı dijital bilgilerin ve iletişim teknolojilerinin neden olduğu büyük sosyal, siyasal, ekonomik ve kültürel değişimlere dikkat çekmiş ve söz konusu dönüşümleri "ağ toplumu" kavramını kullanarak açıklamıştır.

Günümüzde şirketler çalışanlarıyla iletişimde kalabilmek adına WhatsApp grupları kuruyor; devlet mekanizmaları Facebook ve Twitter üzerinde sayfalar oluşturup halkla ilişkilerini bu platformlar 
üzerinden yürütüyor; sanatçılar Instagram aracıllı̆gıla evlerinden konser verip binlerce insan tarafindan dinlenebiliyor; bir yönetmen çıkacak olan filminin fragmanını YouTube'da yayınlıyor ve geleneksel medyada olanın aksine, tüm bu örneklerde hedef kitle de anlık olarak iletişim sürecine dâhil olup üretilen içeriği şekillendirebiliyor. Geleneksel medyada olduğu gibi söz sahibi olmak için "medya sektörünün içinde olma" gerekliliği sosyal medya söz konusu olduğunda geçerliliğini yitirmektedir, çünkü medya artık her yerdedir ve insanlar bu platformlarda kendi içeriklerini üretebilmektedir. Hemen her şeyde olduğu gibi sosyal medya söz konusu olduğunda da avantajların yanında dezavantajlardan da bahsetmek mümkündür.

Drahošováa ve Balcob (2017: 1008-1009) sosyal medya kullanımının avantajlarını Avrupa Birliği özelinde inceleyerek şu şekilde bir listeleme yapmışlardır: 1-Bilgi paylaşımı ve iletişim, 2-eğitim, 3-veri paylaşımı, 4-takım hâlinde ve evden çalışma, 5-hizmetler, 6-teçhizat ve ekipman paylaşımı. Aynı araştırmacılar, sosyal medya kullanımının dezavantajlarını ise şu şekilde listelemişlerdir: 1-İnternet bağımlılı̆̆ı, 2-güvenlik açığı, 3-bilgi kirliliği, 4-temas hâlinde olunanlarla iletişimin kesilmesi, 5-diğer. Ahmad (2021) ise sosyal medyanın toplumsal yaşam için on avantajını 1-bağlantı sağlama, 2-eğitim alma, 3-yardım alma, 4-bilgi ve güncellemelerden haberdar olma, 5-reklam yapma, 6-asil bir amacı gerçekleştirme, 7-farkındalık oluşturma, 8-hükumet ve devlet dairelerinin suçla mücadelesine yardım etme, 9-iş yerlerinin itibarını artırma ve 10-topluluk oluşturmaya yardım etme şeklinde sıralarken sosyal medyanın toplumsal yaşam için on dezavantajını 1-siberzorbalık, 2-kullanılan hesabın başkalarının eline geçmesi, 3-bağımlılık, 4-dolandırıcılık ve sahtekârlık, 5-güvenlik sorunları, 6-itibar kaybı, 7-aldatma ve ilişki sorunları, 8-sağlık sorunları, 9-ölüme sebebiyet verme ve 10-uyuşturucu madde ve alkol kullanımına özendirme şeklinde sıralamıştır.

Yukarıdaki maddelerden her birisi ayrı bir çalışmayı gerektirecek kapsamda olsa da risk toplumu açısından özellikle önem arz eden nokta, sosyal medyanın güvenlik ve gizlilik açısından birtakım sorunları beraberinde getirmesidir. Kamusal alan-özel alan ayrımını bulanıklaştıran sosyal medya, özel hayatın güvenliği ve gizliliği söz konusu olduğunda birtakım şaibelere ortam hazırlaması bakımından başarılı bir test verememiş̧ir. Özel yaşam kavramı ilk defa 10 Aralık 1948 tarihinde yayınlanan İnsan Hakları Evrensel Bildirgesi’nde kullanılmıştır. Bildirge'nin 12. maddesi şu şekildedir: "Hiç kimsenin özel yaşamına, ailesine, evine ya da yazışmasına keyfi olarak karışılamaz, onuruna ve adına saldırılamaz. Herkesin, bu gibi müdahale ya da saldırılara karşı yasa tarafından korunma hakkı vardır”. Sosyal medyanın kamusal alan-özel alan ayrımını bulanıklaştırması, daha önce çoğunlukla özel alana ait bilgilerin mahrem statüsünde değerlendirilmesi durumunun da ortadan kalkmasına zemin hazırlamıştır. Öyle ki, artık kamusal alana fiziksel olarak çıkmaya gerek duymadan hane dışındakilere hane içinin kapıları aralanmaktadır. Hane içini gösteren fotoğraf ve videolar veya bir alışveriş merkezinde çekilen bir ürünün fotoğrafının evinden çıkmamış birisiyle anlık olarak paylaşılması 
Ulrich Beck ve Anthony Giddens'ın Risk Toplumu Kavramsallaştırması Işığında Sosyal Medya ve Bilginin Güvenliği ve Gizliliği İlkesi

kamusal alan ve özel alan arasında kesin ayrımların ortadan kalktığını ve her iki alanda üretilen bilginin de özel sayılabileceğine işarettir.

Günümüzde, tarih boyunca karşılaşılan herhangi bir insan grubundan daha çok kendimizle ilgili bilgi veriyor ve veri toplanmasının önüne geçemiyoruz. Çevrimdışı olan yaşantılarımız artık çevrimiçi ve e-ticaret, anlık mesajlaşma, tanıdıklarla iletişimde kalma gibi çevrimiçi yararlar sebebiyle kişisel bilgilerimizi bir nevi takas ediyoruz. Günümüzde verilerin yaşa, cinsiyete, gelire, yaşanılan şehre, beğenilere, girilen sitelere vb. göre kümelendiği ve insanların veri setleri olarak davranışları üzerinden gruplandırıldığı bilinmektedir. Bu gruplar ise daha sonra satış yapmak isteyen reklamcılara kiralanmakta veya satılmaktadır (Craig ve Ludloff, 2011: 1-2). "Büyük veri” ("big data”) şeklinde kavramsallaştırılan bu durum, dijital çağda doğru ürün veya hizmetin doğru alıcıya ulaşmasını sağlamak gibi avantajların yanı sıra, birtakım risklere de işaret etmektedir. "Elde edilen veri setleri güvenli bir şekilde muhafaza edilmekte midir?", "Bu veriler iddia edildiği gibi yalnızca reklam şirketlerine mi ulaşmaktadır?", "Veriler fişleme aracı olarak kullanılabilir mi?” gibi sorular dijital çağın belirsizliklerinin başında gelmektedir ve dolayısıyla da içinde bulunduğumuz dönemin başlıca risk faktörlerindendir.

Her geçen gün biraz daha büyüyen dijital dünyada üretilen veriler; riskler ve belirsizliklerle şekillenen risk toplumunda hem küresel hem de bireysel çapta bir sorun hâlini almaktadır. Öte yandan, Craig ve Ludloff’a (2011: 4) göre, büyük veri yalnızca verinin boyutu kapsamında değil, aynı zamanda mevcut farklı veri kaynakları ve türleriyle birlikte bu verilerin büyük çoğunluğunun kullanıcılar tarafından üretiliyor olması çerçevesinde de değerlendirilmelidir. Bu araştırmacılara göre, dijital dünyanın \%70'i e-postalar, Facebook, Twitter, LinkedIn, Flickr, YouTube vs. aracılığıyla kullanıcılar tarafından inşa edilmektedir. YouTube üzerinde 70 milyon civarında video bulunmakta ve bunlar günlük olarak yaklaşı 100 milyon kez izlenmekte; 29 milyardan fazla tweet bulunmakta ve her geçen gün bunlara üç milyon kadar daha eklenmekte; 500 milyondan fazla aktif Facebook kullanıcısı bulunmakta ve bunlar ayda 700 milyar dakikadan fazla süreyi Facebook'ta geçirmektedir. Tablo 1'de dünyadaki sosyal ağ kullanıcılarının 2017'den 2025'e kadarki sayısı gösterilmektedir:

Tablo 1: 2017'den 2025'e Dnyada Sosyal Ağ Kullananların Sayısı (Milyar), *Öngörü 


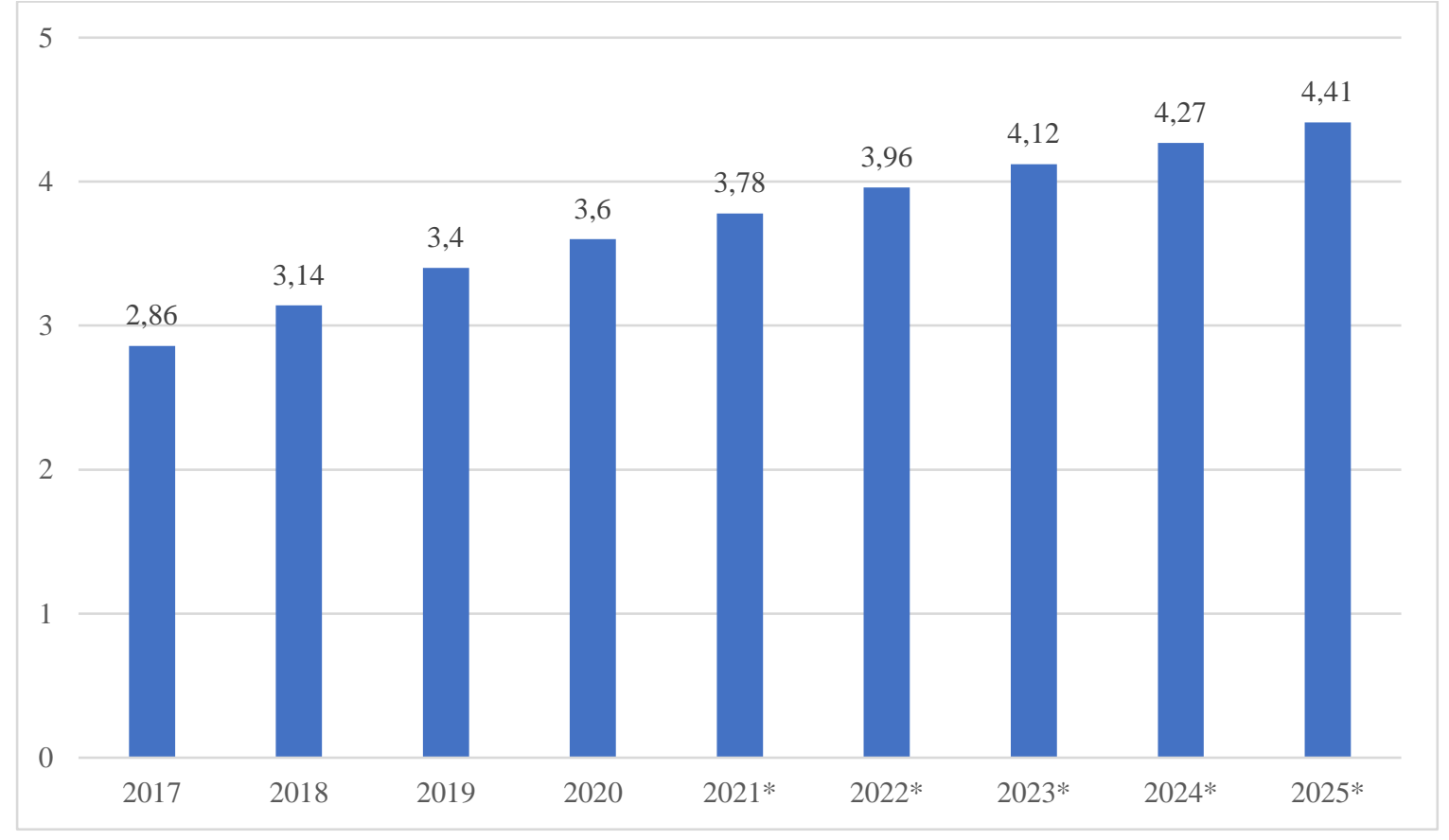

Kaynak: statista, 2020.

2025 y1lı itibariyle 4,41 milyar insanın kullanacağı öngörülen sosyal medya platformları, teknolojinin doğurduğu modern bir risk olarak bilginin güvenliği ve gizliliğini hemen herkes için gündeme getirmektedir. Risk toplumunda kişisel verileri hükumet organlarından veya reklam şirketlerinden (ve başka bireylerden) saklamak sosyal ağ kullanarak geçirilen zamanın artmasından dolayı giderek daha zor bir hâl almaktadır. Peki kişisel verilerin sızdırılması yalnızca bir söylenti midir, yoksa bunun bir gerçeklik payı var mıdır?

Genel anlamda bütün sosyal medya platformlarında verilerin düzenli olarak sızdırıldığına dair somut deliller olmamasına rağmen, "Facebook veri skandalı" olarak bilinen olaylar silsilesine bakmak, böyle bir riskin süregelen varlığını ortaya koyacaktır. Facebook'un veri güvenliğini sağlamadaki yetersiz önlemleri nedeniyle 2005 yılından başlayarak özellikle 2018 y1lında yoğunlaşan veri skandalıyla ilgili tartışmalar günümüze kadar devam etmektedir. Söz konusu skandal özellikle yaklaşık 87 milyon insanın bilgisinin bir politik danışma ve stratejik iletişim şirketi olan Cambridge Analytica tarafindan toplanması etrafında şekillenmiştir. Cambridge Analytica ve SCL Group, Emerdata, Cubeyou ve Onavo gibi bazı diğer şirketler veri kaçakçıllğına karşı yetersiz önlemler, Facebook geliştiricilerinin gözetim azlığı ve kullanıcıların oldukça geniş hüküm ve koşulları kabul etmeleri gibi nedenlerden dolayı, kullanıcıların kişisel verilerine erişme imkânı sağlamışlardır. Skandala Cambridge Analytica özelinde bakıldığında, şirketin thisisyourdigitiallife adlı bir uygulama ile verileri ele geçirdiği anlaşılmıştır. Masum bir uygulama gibi görünen thisisyourdigitiallife, Facebook hesabına eklenip kullanılmaya başlanınca hem kullanıcıların hem de bunların arkadaşlarının profil bilgilerine ve kullanıcı geçmişine erişim sağlamaktadır. Veri, uygulamayı kullanmaya başlayan hesabın ve hesaptaki 
Ulrich Beck ve Anthony Giddens'ın Risk Toplumu Kavramsallaştırması Işığında Sosyal Medya ve Bilginin Güvenliği ve Gizliliği İlkesi

arkadaşların Facebook’ta beğeni bıraktı̆̆ı paylaşımları da kapsamaktadır (Patterson, 2020). Kosinski, Stillwell ve Graepel (2013) bu uygulamanın otomatik olarak ve isabetli bir şekilde cinsel eğilim, etnisite, dini ve siyasi görüş, kişilik özellikleri, zekâ ve mutluluk seviyesi, uyuşturucu madde bağımlılı̆̆ı, ebeveynlerin ayrı olup olmadığı, yaş ve cinsiyet gibi son derece hassas kişisel bilgileri saptadığını iddia etmişlerdir.

Sosyal medyanın yalnızca Facebook'tan ibaret olmadığ 1 bir gerçektir ancak sosyal medyada bir tekelleşmeye doğru gidildiği de gözden kaçırılmamalıdır. Öyle ki, son on yılın en çok indirilen dört uygulamasının (Facebook, Facebook Messenger, WhatsApp ve Instagram) her biri Facebook'a aittir. 2010-2019 yılları arasında en çok indirilen uygulama Facebook'un ana uygulamasıyken ikinci en çok indirilen uygulama Facebook Messenger olmuştur. Bu dönemde üçüncü en çok indirilen uygulama WhatsApp, dördüncü en çok indirilen uygulama ise Instagram olmuştur. Facebook’tan bağımsız olarak çıkış yapan WhatsApp ve Instagram sırasıyla 2012 ve 2014 yıllarında Facebook tarafindan satın alınmıştır (Shead, 2019). Sosyal medyada hâlihazırda büyük bir pazara sahip olan Facebook, tekelleşme yolunda attığı adımlarla dijital dünyayı yönetme konusunda biraz daha güç kazanmıştır.

Sosyal medyanın kullanıcılar tarafından tepki çeken hamlelerinden birisi de bir anlık iletişim uygulaması olan WhatsApp Hizmet Koşulları ve Gizlilik İlkesi'ni değiştirme kararı aldığında yaşanmıştır. Yapılan güncellemeyle 8 Şubat 2021 tarihi itibariyle uygulamaya konulacak olan şartların kullanıcılar tarafından yine bu tarihe kadar kabul edilmesi istenmiş, kabul etmeme durumunda ise WhatsApp kullanmaya devam edilemeyeceği bildirilmiştir. Avrupa Birliği üyesi ülkeleri etkilemeyen bu durum, diğer ülke vatandaşlarını endişelendirmiş ve birçoklarının bu konuyla ilgili harekete geçmelerini sağlamıştır. Bunun nedeni, yapılan güncellemenin "Facebook Şirketlerinin bir parçası olan WhatsApp, diğer Facebook Şirketlerinden bilgi alır ve bu şirketlerle bilgi paylaşımında bulunur." ifadesini içererek kullanıcılarda özel hayatın güvenliği ve gizliliği ilkesinin ihlal edildiğine yönelik bir alg1 yaratmış olmasıdır. Bu sürecin ardından; YouTube, Twitter ve ironik olarak WhatsApp ve Facebook gibi sosyal medya platformları üzerinden WhatsApp kullanmayı bırakıp Telegram, Signal gibi alternatiflere yönelmenin daha doğru olacağına dair bir kamuoyu oluşturulmuştur. \#WhatsAppiSiliyoruz kampanyası Türkiye özelinde büyük ses getirmiştir ve uzunca bir süre gündemde kalmıştır. Sürecin yanlış anlaşıldığını ifade eden yetkililer, sözleşmeyi kabul etmek için verilen süreyi 15 Mayıs 2021 tarihine kadar ertelemişlerdir (“Habertürk”, 2021; "Hürriyet”, 2021). 15 Mayıs 2021 sonrasında ise yeni ilkeleri kabul etmeyen kullanıcıların hesapları silinmemiş ancak uygulama üzerinde yapabilecekleri sınırlandırılmıştır.

Yukarıdaki örneklerde kullanıcıları endişelendiren durum, tam olarak risk toplumu kavramsallaştırmasında görüldüğü gibi teknolojik bir gelişmenin sonucunda bireylerin başlarına gelecek durumu bilememeleri, kestirememeleridir. İnsanlar verilerinin bilinmeyen kaynaklarla paylaşılması 
durumunda başlarına neyin gelebileceğini öngöremedikleri için risk olgusunun sonuçlarıyla baş etmek zorunda kalmışlardır. Bu mücadele süreci incelendiğinde görülmektedir ki risk, küresel bir boyuta ulaşmıştır ancak riskin sonuçlarıyla baş etmek için bireysel değişimler gerekmektedir. WhatsApp örneğine bakıldığında, kullanıcılar için şahsi bilgilerin üçüncü taraflarla paylaşılması bir risk unsurudur, çünkü bu paylaşımların sonucunda olabilecekleri önceden bilmek mümkün görünmemektedir. $\mathrm{Bu}$ durumda iki seçenek vardır: sözleşmeyi kabul etmek veya sözleşmeyi reddetmek. Her iki seçenek de bireyin kendi kararına kalmıştır. Sözleşmeyi kabul etmek, kullanıcıların bakış açısından söz konusu riski de kabul etmek anlamını taşımaktayken sözleşmeyi reddetmek bu riski ortadan kaldırmak demektir. Diğer yandan, WhatsApp gibi yaygın kullanım oranına sahip bir uygulamayı kullanmamak, içinde yaşadığımız küresel dünyada hem ulusal hem de uluslararası anlamda iletişimsizlik riskini doğurmaktadır. Dolayısıyla, bir riskin ortadan kaldırılması, diğer bir riskin ortaya çıkmasıyla sonuçlanır ve bu anlamda risk toplumunda riskin her an her yerdeliği savı doğrulanmış olur.

Risklerin sonuçlarıyla bireysel olarak baş etme gerekliliği bununla sınırlı değildir. Smith vd. (2013: 2) sosyal medyada özel hayat tartışmalarının iki boyutuna dikkat çekmişlerdir: Büyük veriyle bağlantılı olan tehditler başkaları tarafından yaratılan sorunlar olarak değerlendirilmektedir. Buradaki temel risk, bilgilerin istenmeyen tarafların eline geçmesi ve bu durumda neler olabileceğinin bilinmemesidir. Bunun dışında, sosyal medya kullanıcılarının kendi yarattıkları sorunlar vardır. Örnek olarak, bir kullanıcının kendisiyle alakalı herhangi bir açıdan uygunsuz sayılabilecek bir fotoğrafı özel bir albüme koymak yerine başkalarının da görebileceği bir albüme koyması düşünülebilir. Sosyal medya kullanıcısı yapacağı paylaşımları oluşabilecek her türlü riske karşı bizzat kontrol etmelidir. Paylaşılan ortam dosyaları dışında; yapılan yer bildirimleri, beğeniler ve yorumlar da benzer riskler taşımaktadır. Refleksif modernite, failin kendi eylemleri üzerine düşünmesi ve bilinçli adımlar atması gerekliliğini doğurmaktadır. Buradan da anlaşılabileceği gibi, dijital dünyada atılacak (veya atılmayacak) her adım, o adımla ilişkili risklere karşı bilinçli olmayı gerektirir.

\section{Sonuç Yerine}

İnsanlara kendisinden önceki dönemlerden daha fazla imkân, seçenek ve özgürlük sunuyor gibi görünen dijital çağ, yaşanılan teknolojik gelişmeler 1şı̆̆ında bir 19. yüzyıl fütüristinin ütopik tahayyülüne uygun toplumsal görüntüler ve yaşam tarzları sağlıyor olabilir. Küresel iletişim devrimi sonucu medya geleneksel ve yeni olmak üzere ikiye ayrılmış, ikinci kategoriye dâhil edilen sosyal medya ise farklı fikirlerin dile getirilebildiği ve dünyanın öteki ucunda neler olduğunun anlık olarak birinci ağızdan öğrenilebildiği bir araç olarak hayatlarımıza girmiştir. Cinsiyet, dil, din, ırk, gelir durumu, medeni durum, yaşanılan yer gibi değişkenlere bakılmaksızın bireylerin katılımına izin veren sosyal medya platformları, sosyal bir varlık olan insana iletişim ihtiyacı anlamında belli başı faydalar 
Ulrich Beck ve Anthony Giddens'ın Risk Toplumu Kavramsallaştırması Işığında Sosyal Medya ve Bilginin Güvenliği ve Gizliliği İlkesi

sağlamıştır. Ancak yaratılan bu liberal atmosferin içerisinde karanlık bir yan da mevcuttur. Mevcut çalışmada sosyal medyanın bu karanlık tarafinda duran bazı noktalar açıklanmaya çalışılmıştır.

Post-modernistler, içinde bulunduğumuz dönemi moderniteden bir kopuş olarak değerlendirirlerken geç modernistler, modernitenin sonunun geldiği değil, dönüşüme uğradığ1 argümanını savunmaktadırlar. Bu bağlamda, modernitenin bilgi, akılcılık, düşünme, ilerleme, gelişme gibi anahtar kavramları, yerlerini yeni kavramlara bırakmamış, aksine etkilerini artırmışlardır. Dijital çağ ve risk toplumu bir arada düşünüldüğünde Beck ve Giddens'ın iddialarının her zamankinden daha geçerli olduğu anlaşılmaktadır. Dijital çağda bilimsel ve teknolojik gelişmeler daha fazla, daha çevreleyici ve daha ciddi sonuçları olan bir tür risk algısını hayatlarımıza sokmuştur. Yaşanan iletişim devriminden sonra Beck'in ikinci modernitesinin yerini yavaş yavaş üçüncü moderniteye bıraktığını söylemek mümkündür. Oluşan bu üçüncü modernite temelde "Facebook neslinin" ortaya çıkması ve ortalama insanın dünyayı dönüştürmesi gibi durumlar çerçevesinde şekillenmektedir (De Vulpian, 2008). Peki, bu durum insanlık (ve doğa) için müjdeli bir haber midir, yoksa çığırından çıkmış bir risk toplumunun ayak sesleri mi? Belki de bu soruya verilebilecek en iyi cevap Facebook'un kurucusu Mark Zuckerberg'ün şu sözlerinde saklıdır: "En büyük risk, hiç risk almamaktır... Çok hızlı değişen bir dünyada başarısızlığa uğratacağı kesin olan tek strateji, risk almamaktır” (Wundenberg, 2019).

\section{Kaynakça}

Ahmad, B. (2021, 1 Şubat). 10 advantages and disadvantages of social media for society. Erişim adresi: https://www.techmaish.com/advantages-and-disadvantages-of-social-media-for-society

Beck, U. (1992). Rısk society: Towards a new modernity (M. Ritter, Çev.). Londra: Sage Publications.

Beck, U. (1998b). Politics of risk society, J. Franklin (Ed.), The politics of risk society kitabı içinde (s. 9-22). Cambridge: Polity Press.

Brown, J. M. (2015, 20 Kasım). The etymology of risk. Erişim adresi: https://thereformedbroker.com/2015/11/20/the-etymology-of-risk/

Craig,T. ve Ludloff, M. E. (2011). Privacy and big data. Sebastopol: O’Reilly Media.

De Vulpian, A. (2008). Towards the third modernity: How ordinary people are transforming the world. Charmouth: Triarchy Press.

Drahošováa, M. ve Balcob, P. (2017). The analysis of advantages and disadvantages of use of social media in European Union. Procedia Computer Science, 109, 2017, 1005-1009.

Durkheim, É. (1964). The division of labor in society. New York: Free Press.

Ekberg, M. (2007). The parameters of the risk society: A review and exploration. Current Sociology, 55 (3): 343-366.

Esgin, A. (2013). İmal edilmiş belirsizlikler çağının sosyolojik yönelimi: Ulrich Beck ve Anthony Giddens kaynaklı "risk toplumu" tartı̧̧maları. Gaziantep Üniversitesi Sosyal Bilimler Dergisi, $12(3), 683-696$.

Evre, B. (2011). Geç modern veya postmodern bağlamda değişen siyasetin yeni biçim(ler)i. LAÜ Sosyal Bilimler Dergisi, 2 (1), 65-75. 
Giddens, A. (1996). The consequences of modernity. Cornwall: Polity Press.

Giddens, A. (2000). Runaway world: How globalisation is resharping our lives. New York: Routledge.

Habertürk. (2021, 11 Ocak). WhatsApp sözleşmesi 2021 nedir, ne anlama geliyor? WhatApp gizlilik sözleşmesi nasıl iptal edilir? Erişim adresi: https://www.haberturk.com/whatsapp-sozlesmesinedir-ne-anlama-geliyor-whatapp-gizlilik-sozlesmesi-nasil-iptal-edilir-2932352-teknoloji

Hürriyet. (2021, 16 Ocak). WhatsApp'tan gizlilik sözleşmesi açıklaması! Geri adım attılar. Erişim adresi: https://www.hurriyet.com.tr/teknoloji/son-dakika-whatsapptan-gizlilik-sozlesmesiaciklamasi-tarihi-geri-aliyoruz-41715997

Kosinski, M., Stillwell, D. ve Graepel, T. (2013). Private traits and attributes are predictable from digital records of human behavior. PNAS, 110 (15), 5802-5805. https://doi.org/10.1073/pnas.1218772110

Lash, S. ve Friedman, J. (1992). Introduction: Subjectivity and modernity's other. S. Lash ve J. Friedman (Ed.), Modernity and identity kitabı içinde (s. 1-30). Oxford: Blackwell.

Linehan, D. (2009). Modernity. R. Kitchin ve N. Thrift (Ed.), International encyclopedia of human geography volumes one to twelve kitabı içinde (s. 157-163). Oxford: Elsevier.

Luhmann, N. (2000). Familiarity, confidence, trust: Problems and alternatives. G. Diego (Ed.), Trust: Making and breaking cooperative relations kitabı içinde (s. 94-107). Oxford: Wiley-Basil Blackwell.

Lyotard, J. (1984). The postmodern condition: A report on knowledge (G. Bennington ve B. Massumi, Çev.). Minneapolis: University of Minnesota Press.

Marx, K. (1973) Grundrisse: foundations of the critique of political economy. Harmondsworth: Penguin.

Patterson, D. (2020, 30 Temmuz). Facebook data privacy scandal: A cheat sheet. Erişim adresi: https://www.techrepublic.com/article/facebook-data-privacy-scandal-a-cheat-sheet/

Ray, Larry. (2007). Globalization and everyday life. New York: Routledge.

Shead, S. (2019, 18 Aralık). Facebook owns the four most downloaded apps of the decade. Erişim adresi: https://www.bbc.com/news/technology-50838013

Shilliam, R. (2017). Modernity and modernization. R. A. Denemark (Ed.), The international studies encyclopedia volume VIII kitabı içinde (s. 5214-5232). Malden: Wiley-Blackwell.

Slattery, M. (2010). Sosyolojide temel fikirler (Ü. Tatlıcan, Çev.). İstanbul: Sentez Yayıncılık.

Smith, M., Szongott, C., Henne, B. ve Von Voigt, G. (2013). Big data privacy issues in public social media. 6th IEEE International Conference on Digital Ecosystems and Technologies (DEST), 18-20 Haziran 2012, Campione d'Italia, Bildiriler kitabı içinde (s. 1-6). İtalya: IEEE Xplore.

Sociology Guide. (2021). Post modernism. Erişim adresi: https://www.sociologyguide.com/postmodernism/

statista. (2020, Temmuz). Number of social network users worldwide from 2017 to 2025. Erişim adresi: https://www.statista.com/statistics/278414/number-of-worldwide-social-network-users/

Uludağ, Z. (2020). Risk toplumunda sosyal medyanın rolü (Yüksek Lisans Tezi). Kırıkkale Üniversitesi Sosyal Bilimler Enstitüsü, Kırıkkale.

Üvez, F. (2014). Medya ve risk toplumu ilişkisi bağlamında terör haberlerinin analizi (Yüksek Lisans Tezi). Atatürk Üniversitesi Sosyal Bilimler Enstitüsü, Erzurum.

Van Dijk, J. (2006). The network society. Londra: SAGE Publications. 
Aykut SIĞIN

Ulrich Beck ve Anthony Giddens'ın Risk Toplumu Kavramsallaştırması Işı̆̆ında Sosyal Medya ve Bilginin Güvenliği ve Gizliliği İlkesi

Wundenberg, Z. (2019, 6 Mayıs). Not taking a risk is the biggest risk of all. Erişim adresi: https://www.canberratimes.com.au/story/6107725/not-taking-a-risk-is-the-biggest-risk-ofall/\#: : :text=out $\% 20$ what $\% 20$ could.

,Mark\%20Zuckerberg\%20famously $\% 20$ said $\% 3 \mathrm{~A} \% 20 \% 22$ The $\% 20$ biggest $\% 20$ risk $\% 20$ is $\% 2$ 0not\%20taking,he\%20might\%20be\%20onto\%20something 